\title{
Differences in cellular immune responses of mice BALB/c to low and high infective doses of Trichinella spiralis
}

\author{
E. DVOROŽŇÁKOVÁ*, M. JALČOVÁ, Z. HURNÍKOVÁ
}

\begin{abstract}
Institute of Parasitology of the Slovak Academy of Sciences, Hlinkova 3, 04001 Košice, Slovak Republic,
\end{abstract}
*E-mail:dvoroz@saske.sk

\begin{abstract}
Summary
The study was focused on a role of lymphocytes and macrophages in the immune response of mice to Trichinella spiralis infection with low (10) and high (400) infective doses of larvae. The light infection stimulated the proliferation of splenic $\mathrm{T}$ lymphocytes only during the intestinal phase of the infection, till day 15 post infection (p.i.), but the heavy infection activated $\mathrm{T}$ cells during the migration of newborn larvae (from day 20 to 30 p.i.). B cell proliferation was markedly stimulated after the heavy infection. The light infection increased the presence of helper CD4 cells till day 10 p.i. in contrast to the heavy infection, but subpopulation of CD8 $\mathrm{T}$ cells was not influenced by a different size of infective dose. Cytokine production of IL-5 and IFN- $\gamma$ was not markedly affected by the light infection in contrast to the heavy infection that stimulated IL-5 synthesis during the whole experiment and IFN- $\gamma$ during the migration of newborn larvae. The light infection stimulated a metabolic activity of peritoneal macrophages already in the intestinal phase, but the heavy infection affected their activity only in the muscle phase of the infection.
\end{abstract}

Keywords: Trichinella spiralis; $\mathrm{T}$ and $\mathrm{B}$ lymphocytes; cytokines IL-5; IFN-gamma; macrophages

\section{Introduction}

Trichinella spiralis is the intestinal nematode parasite with worldwide distribution and which causes trichinellosis - a serious zoonosis (Paraličová et al., 2009; Oltean et al., 2012). Although Trichinella can be maintained solely in a sylvatic cycle, the role of wildlife as a reservoir is an important potential source of infection for domestic animals and humans. Small mammals represent an important part of the epidemiology of Trichinella spp. transmission. Moreover, synanthropic rodents are an important reservoir of trichinellosis in the domestic cycle (Hurníková et al.,
2009). In experimental studies, high infective doses (200 500 muscle larvae per mouse) are generally used to provoke strong immune response. In natural conditions, however, wild animals could be infected more frequently by a low number of larvae. From this point of view, such immunological and serological studies are rare. Experimental studies demonstrate the dependence of infective dose on the effectiveness of infection (Kapel \& Gamble, 2000; Cui et al., 2006; Reiterová et al., 2009).

Infectivity of Trichinella spiralis is also determined by the immune status of the host, host's immune and inflammatory responses to Trichinella antigens (Bolas-Fernández, 2003). The complete life cycle of Trichinella spp. occurs in one host, which means that the host can exert its immune attack at several points in the life cycle. Adult worms reproduce in the small intestine, new-born larvae migrate through the blood and lymphatics to the skeletal muscle cells, and encapsulated larvae (L1) represent the infective stage of the parasite (Despommier, 1998). Every stage of the life cycle of trichinella can evoke a stage-specific protective host immune response due to the uniqueness in both the cuticular antigens and the excretion/secretion antigens of each stage (Wang, 1997). The mechanism of expulsion of worms is dependent on the Th2 type of response, what leads to the activation of mucosal mast cells (Khan et al., 2001). CD4+ T helper type 2 cells are critical in host protective immune and inflammatory responses during trichinella intestinal infection. Muscle infection elicites a chronic infection where a major role in host defense processes is played by cellular immunity (Mahida, 2003). Larvae survive in nurse cells in close association with macrophages, $\mathrm{CD} 8+$ and $\mathrm{CD} 4+\mathrm{T}$ lymphocytes, and $\mathrm{B}$ lymphocytes. B lymphocytes secreting antibodies, particularly IgG and IgE, may lead to an effective antibodydependent cell mediated cytotoxic reaction against newborn larvae (Beiting et al., 2004).

Potential differences in a development of the host immune 
response to different infective doses of Trichinella and host-parasite interactions are rarely studied. Experimental studies on mice could demonstrate how a different dose of infective larvae may have influenced the nature and degree of the host immune and inflammatory responses, the complex interplay between immunogenicity and pathogenicity influencing both host and parasite, how the parasite affects host capacity to develop the Th cell response necessary for resistance, cytokine production and kinetics of specific antibodies (Wakelin et al., 2002; Bolas-Fernández, 2003).

The aim of this study was to compare the development of $\mathrm{T}$ cellular response and macrophage's activation in mice after $T$. spiralis infection with the low dose of 10 larvae and high dose of 400 larvae.

\section{Materials and methods}

\section{Experimental design}

The experiment was carried out on male BALB/c mice (n $=104$ ) weighting $18-20 \mathrm{~g}$. Mice were kept under a $12-\mathrm{h}$ light/dark regime at room temperature $\left(22-24{ }^{\circ} \mathrm{C}\right)$ and $56 \%$ humidity on a commercial diet and water. The experimental protocol was approved by the Institute of Parasitology SAS Animal Care Commitee. Animals were divided randomly into three groups as follows: Group 1 (n $=24)$ was uninfected (control), mice in Group $2(\mathrm{n}=40)$ were infected per os with 400 Trichinella spiralis larvae per mouse on day 0 of the experiment (heavy infection). Mice in Groups $3(\mathrm{n}=40)$ were infected per os with $10 T$. spiralis larvae per mouse on day 0 of the experiment (light infection).

Samples of blood, spleen, macrophages, the small intestines and muscles were obtained from three mice of control and five of infected groups on days: 0 (prior infection), 5 , $10,15,20,30,45$ and 60 post infection (p.i.).

\section{The infective larvae Trichinella spiralis}

The reference isolate of Trichinella spiralis (ISS 004) (obtained and assigned codes from the Trichinella Reference Centre in Rome), maintained by serial passage in ICR mice at the Institute of Parasitology SAS, was used for the infection. Larvae were released by artificial digestion ( $1 \%$ pepsin, $1 \% \mathrm{HCl}$ for $4 \mathrm{~h}$ at $37^{\circ} \mathrm{C}$ ) of tissue following the standard protocol and kept saline solution until inoculation of experimental mice.

\section{Intestinal worm burdens}

The intestinal phase of infection was investigated on days $5,10,15,20$ and 30 p.i. The small intestine was cut into 5 $-10 \mathrm{~cm}$ long pieces, placed into a sieve and incubated in conical pilsner glasses in $37{ }^{\circ} \mathrm{C} \mathrm{NaCl}(0.9 \%$ saline $)$ overnight. After incubation, gut pieces were discarded and the sediment was counted under stereomicroscope at $60 \mathrm{x}$ magnification.

\section{Isolation of muscle larvae}

The muscle phase of infection was examined on days 20, 30, 45 and 60 p.i. Whole eviscerated carcasses were min- ced and artificially digested (1\% pepsin, $1 \% \mathrm{HCl}$ for $4 \mathrm{~h}$ at $37{ }^{\circ} \mathrm{C}$; both Sigma-Aldrich, Germany) according to Kapel and Gamble (2000). Samples were allowed to settle for $20 \mathrm{~min}$ before the supernatant was discarded and the sediment was poured through a $180 \mu \mathrm{m}$ sieve into a conical glass and washed with tap water. The sediment was finally transferred to a gridded Petri dished and counted using a stereomicroscope at $40 \mathrm{x}$ magnification. Depending on the density of larvae either a sub-sample or the whole sample was counted.

\section{T and B lymphocyte proliferation assay}

The proliferative activity of splenic $\mathrm{T}$ and $\mathrm{B}$ was detected spectrophotometrically using an MTT assay (Dvorožňáková et al., 2012). Briefly, cells $\left(5 \times 10^{6}\right.$ cells /ml RPMI, Sigma-Aldrich, Germany) were incubated with $10 \mu \mathrm{g} / \mathrm{ml}$ of concanavalin A (Con A) (T cells) or lipopolysaccharide (LPS) (B cells) (Sigma-Aldrich, Germany) at $37{ }^{\circ} \mathrm{C}$ in $5 \%$ $\mathrm{CO}_{2}$ and $85 \%$ humidity for 72 hours. $20 \mu$ laliquots of 3,4dimethylthiazolyl 2,5-diphenyltetrazolium bromide (MTT) (Sigma-Aldrich, Germany) (0.1\% solution) were then added to the cell cultures, incubated for $4 \mathrm{~h}$ at $37{ }^{\circ} \mathrm{C}$ and $5 \% \mathrm{CO}_{2}$ followed by centrifugation at $800 \times \mathrm{g}$ for $5 \mathrm{~min}$. The reaction was terminated with dimethylsulfoxide (Sigma-Aldrich, Germany) (200 $\mu \mathrm{l} /$ cell sample) and read at a $540 \mathrm{~nm}$ and $630 \mathrm{~nm}$. The stimulation indices (SI) were calculated according to the formula: $\mathrm{SI}=\mathrm{E}_{540}-\mathrm{E}_{630}$ (stimulated cells) / $\mathrm{E}_{540}-\mathrm{E}_{630}$ (unstimulated cells).

\section{Percentage of CD4+ and CD8+T cells}

Lymphocytes from the spleens and depleted of erythrocytes were resuspended in PBS ( $\mathrm{pH}$ 7.2) at a final concentration of $1 \times 10^{6}$ cells $/ \mathrm{ml}$. The cellular subpopulations were detected by use of rat anti-mouse CD4+ fluorescein isothiocyanate-conjugated and rat anti-mouse CD8+ phycoerythrin-conjugated monoclonal antibodies (BD Biosciences PharMingen, Belgium) at the concentration of $0.4 \mu \mathrm{g} / 10^{6}$ cells at $4{ }^{\circ} \mathrm{C}$ for $30 \mathrm{~min}$. Cells were then washed three times with PBS containing $0.1 \% \mathrm{NaN}_{3}$ and analysed by the FACScan flow cytometer (Becton Dickinson Biosciences, Germany). All data files were analysed with CellQuest software. All data were expressed as a percentage of lymphocytes based on a gate set using forward and side scatter parameters.

\section{Concentration of IFN- $\gamma$ and IL-5 in vitro production}

The capture ELISA was employed to determine the concentration in vitro production of cytokines by splenocytes according to the method of Šltýs and Quinn (1999). Splenocytes for cytokine production were resuspended to $10^{7}$ cells/ml RPMI 1640 medium (Sigma-Aldrich, Germany) and incubated with $10 \mu \mathrm{g} / \mathrm{ml}$ of concanavalin $\mathrm{A}$ at $37{ }^{\circ} \mathrm{C}$ in $5 \% \mathrm{CO}_{2}$ and $85 \%$ humidity. Supernatants were harvested after 72 hours and stored at $-80{ }^{\circ} \mathrm{C}$ prior cytokine determinations. Interferon- $\gamma$ (IFN- $\gamma$ ) and interleukin-5 (IL-5) were used as marker cytokines for Th1 and Th2 responses, respectively. Two pairs of cytokine-specific monoclonal antibodies were used: R4-6A2 and XMG1.2 


\begin{tabular}{|c|c|c|c|c|}
\hline \multicolumn{5}{|c|}{ Intestinal phase } \\
\hline \multirow[b]{2}{*}{ Day } & \multirow{2}{*}{$\begin{array}{c}\text { 400L } \\
\text { Mean } \pm \text { S.D. }\end{array}$} & \multirow{2}{*}{$\begin{array}{c}\text { 10L } \\
\text { Mean } \pm \text { S.D. }\end{array}$} & \multicolumn{2}{|c|}{$\begin{array}{l}\text { Parasite capture from the infective dose } \\
\qquad(\%)\end{array}$} \\
\hline & & & $400 \mathrm{~L}$ & $10 \mathrm{~L}$ \\
\hline 5 & $304.5 \pm 40.5$ & $60.50 \pm 2.07$ & 76.1 & 65.0 \\
\hline 10 & $250.3 \pm 38.9$ & $4.00 \pm 1.67$ & 62.6 & 40.0 \\
\hline 15 & $241.7 \pm 45.0$ & $0.13 \pm 0.35$ & 60.4 & 1.3 \\
\hline 20 & $190.4 \pm 30.6$ & $0.00 \pm 0.00$ & 47.6 & 0 \\
\hline 30 & $20.3 \pm 3.6$ & & 5.1 & \\
\hline
\end{tabular}

for IFN- $\gamma$ and TRFK5 and TRF4 for IL-5 (BD Biosciences PharMingen, Belgium). Results were expressed as pg/ml using murine recombinant IFN- $\gamma$ and IL-5 (BD Biosciences PharMingen, Belgium) as standards. The detection limit of the assay for the both cytokines was $40 \mathrm{pg} / \mathrm{ml}$.

Superoxide anion assay

Generation of extracellular superoxide anion $\left(\mathrm{O}_{2}^{-}\right)$from peritoneal macrophages was assayed as superoxide dismutase (SOD)-inhibitable reduction of ferricytochrome $\mathrm{C}$ with and without stimulation with phorbol myristate acetate (PMA) (Hrčková \& Velebný, 1997). Peritoneal cells were aseptically harvested in RPMI 1640 (Sigma-Aldrich, Germany) to a final concentration of $1 \times 10^{6}$ cells $/ \mathrm{ml}$. One $\mathrm{ml}$ of cell suspension was adhered to each well using $24-$ well plates (Falcon, France) and incubated at $37{ }^{\circ} \mathrm{C}$ in $5 \%$ $\mathrm{CO}_{2}$ and $85 \%$ humidity for $2 \mathrm{~h}$. The reaction was carried out in $0.3 \mathrm{ml} /$ well of $160 \mu \mathrm{M}$ ferricytochrome C (SigmaAldrich, Germany) in Earl's balanced salt solution (EBSS) ( $\mathrm{pH}$ 7.2). In control the reaction was blocked by $300 \mu \mathrm{g}$ SOD/10 $\mu$ in EBSS. $10 \mu \mathrm{l}$ of PMA in ethanol was used for the stimulation of cells for respiratory burst. Cells were incubated at $37{ }^{\circ} \mathrm{C}$ in $5 \% \mathrm{CO}_{2}$ and $85 \%$ humidity for $2 \mathrm{~h}$ and the optical density (OD) of supernatant was measured at $550 \mathrm{~nm}$. The amount of $\mathrm{O}_{2}^{-}$produced was calculated from the difference in OD in reactions blocked by SOD and without SOD. As the resulting value, the nanomols (nmol) of produced $\mathrm{O}_{2}^{-}$were calculated according to the formula: $\mathrm{nmol} \mathrm{O}_{2}{ }^{-}=(\mathrm{OD} / 6.3) \times 100$ and determinated for 1 $\mathrm{mg}$ of cell proteins.

\section{Statistical evaluation}

Statistical differences were assessed using one-way ANOVA, followed by post hoc Tukey's test (a value of
$\mathrm{P}<0.05$ was considered significant), which allowed comparison between each two groups at each time point. The analyses were performed using the Statistica 6.0 (Stat Soft, Tulsa, USA) statistical package.

\section{Results}

Parasite burden - numbers of adults and muscle larvae (Table 1, 2)

Mice infected with the low dose of $T$. spiralis larvae absolutely eliminated parasites from the intestine till day 15 p.i., but after the heavy infection adults persisted in the intestine till day 30 p.i. Parasite burden in the host was comparable in both infections $(62.0-76.13 \%$ of the infective dose). A common biological characteristic used to evaluate Trichinella species infectivity is the index of reproductive capacity $(\mathrm{RCI})$ - ratio of the total number of larvae recovered from an animal to the number of larvae administered to it. The first is the product of 4 components: the number of females established; their fecundity; their reproductive life span; the survival of muscle larvae. At the muscle phase of $T$. spiralis infection RCI was not influenced by a size of the infective dose $(306.0-325.6)$.

Proliferative response of T lymphocytes to Con A (Fig. 1) After the light infection a stimulation of proliferative activity of splenic $\mathrm{T}$ lymphocytes was observed only during the intestinal phase, i.e. from day 5 to 15 p.i. On the contrary, the high infective dose induced the highest values of the proliferative response of T cells from day 20 to 45 p.i., during migration of newborn larvae. Significant diferences $(\mathrm{P}<0.01 ; \mathrm{P}<0.05)$ between infected groups were found in that time.

Table 2. Total larval burden in carcass of mice infected with 10 and $400 \mathrm{~T}$. spiralis larvae

\section{Muscle phase}

\section{L}

\begin{tabular}{|c|c|}
\hline Day p.i. & Mean \pm S.D. \\
\hline 20 & $15908.3 \pm 2420.3$ \\
\hline 30 & $114520.0 \pm 15419.9$ \\
\hline 45 & $125700.0 \pm 5565.1$ \\
\hline 60 & $130266.7 \pm 2419.4$ \\
\hline
\end{tabular}

$10 \mathrm{~L}$

Mean \pm S.D.

$204.2 \pm 84.5$

$2380.0 \pm 1214.8$

$3060.0 \pm 1859.1$

$1800.0 \pm 1182.2$

\section{Reproductive capacity index}

(RCI) 


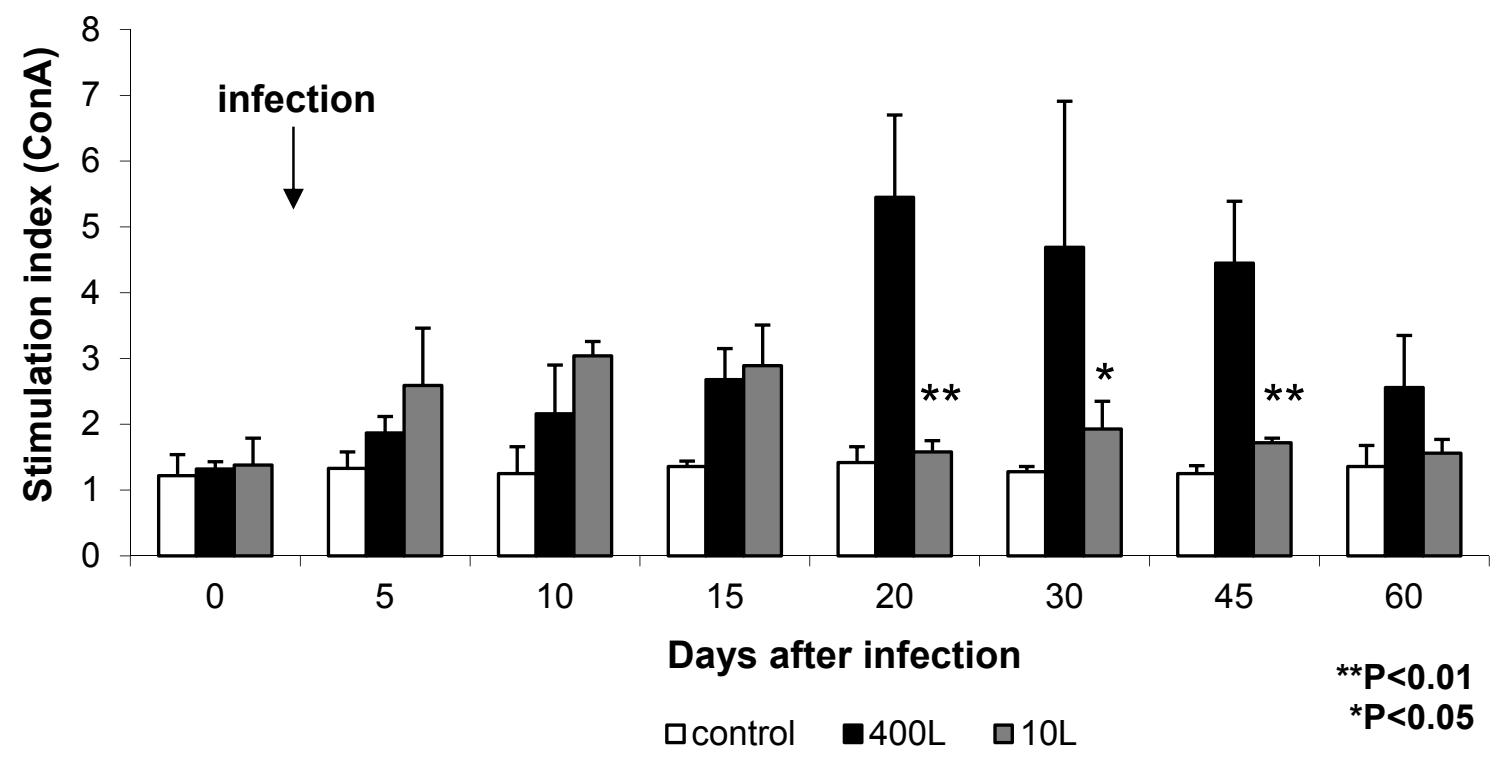

Fig. 1. Proliferative response of T lymphocytes to concanavalin A (Con A) in mice infected with 10 and 400 T. spiralis larvae $*(\mathrm{P}<0.05) ; * *(\mathrm{P}<0.01)$ statistically significant from infection 400 T. spiralis larvae

Proliferative response of B lymphocytes to LPS (Fig. 2)

$\mathrm{B}$ cell proliferation induced with nonspecific mitogen LPS did not differ between both groups till day 15 p.i. Then a striking stimulation of B cells after the heavy infection was observed till the end of the experiment, i.e. day 60 p.i. After the light infection increased values were found till day 45 p.i. Statistically significant differences $(\mathrm{P}<0.05)$ between mice infected with 10 and 400 larvae were recorded on days 20 and 30 p.i.

\section{Numbers of splenic CD4+ and CD8+ T lymphocytes}

(Figs. 3, 4)

Helper CD4 and cytotoxic CD8 lymphocyte subpopulations were evaluated by a percentual occurrence in the spleen of infected mice due to a different splenomegaly in both infections. On the contrary to the heavy infection that did not markedly change the percentage of CD4 T cells, the light infection of mice significantly increased the occurrence of these cells in the spleen on days 5, 10 and 20 p.i. CD8 T cell subpopulation did not show differences in a dependence on a size of infective dose, in both infected groups values of relative percentage increased till day 15 p.i. and persisted at high values till day 30 p.i.

\section{In vitro production of $I L-5$ and IFN- $\gamma$ cytokines}

(Figs. 5, 6)

Cytokines secreted primarily by $\mathrm{T}$ helper cells play a key role in anti-parasite defence and pathology in T. spiralis infection. Th2 cell activation is important in the intestinal phase of trichinellosis. After the light infection there was found the highest in vitro production of Th2 cytokine - IL-5

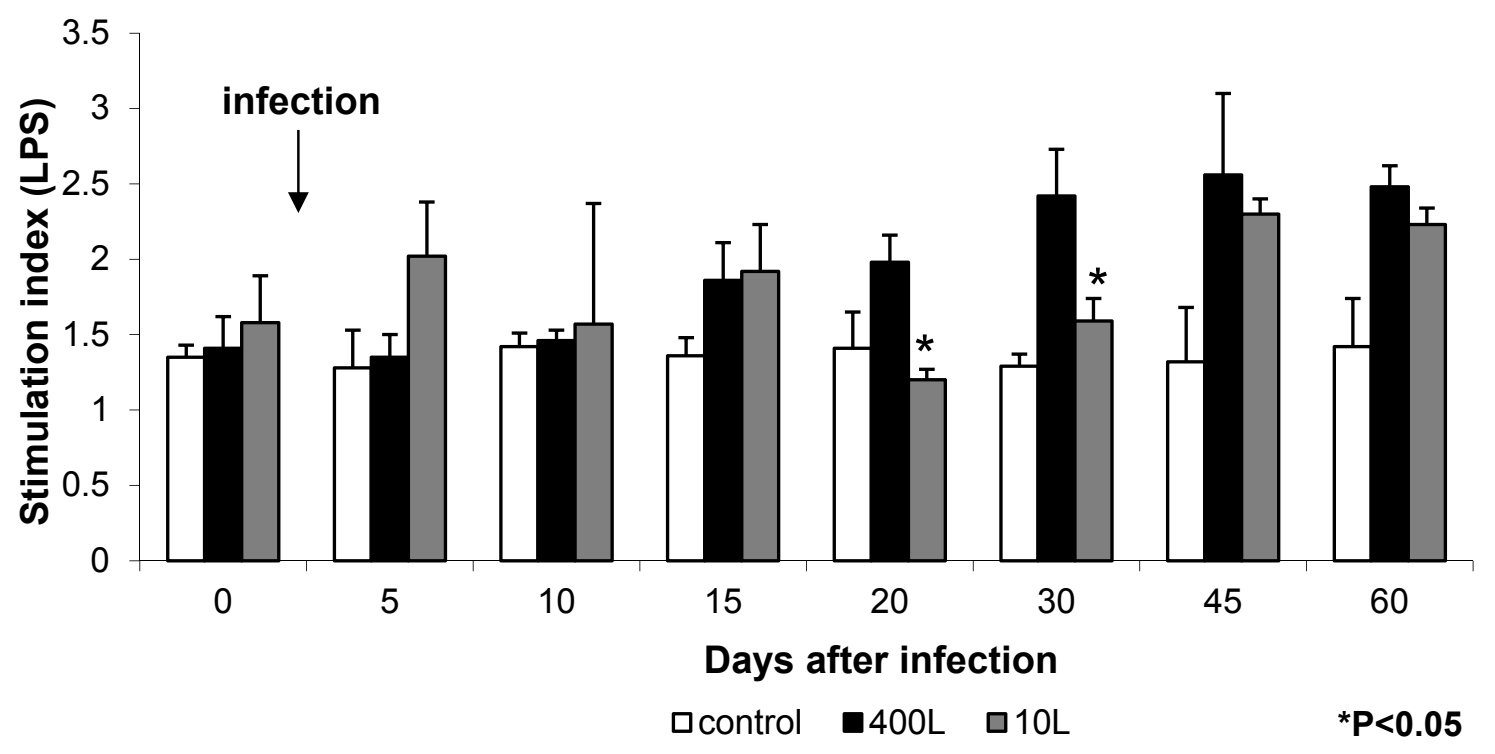

Fig. 2. Proliferative response of B lymphocytes to lipopolysaccharide (LPS) in mice infected with 10 and 400 T. spiralis larvae $*(\mathrm{P}<0.05)$ statistically significant from infection 400 T. spiralis larvae 


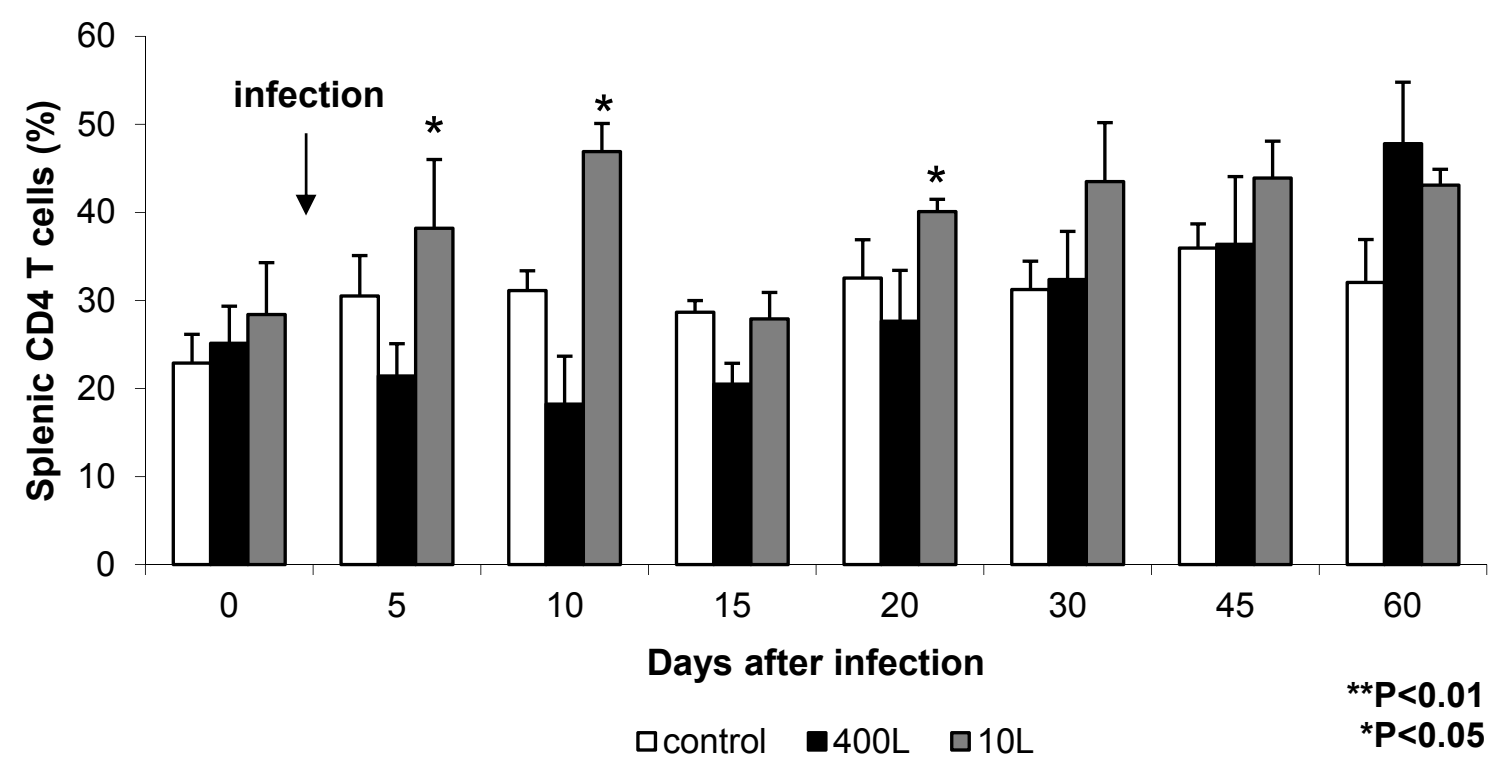

Fig. 3. Relative percentage of splenic CD4+ T cells in mice infected with 10 and 400 T. spiralis larvae $*(\mathrm{P}<0.05) ; * *(\mathrm{P}<0.01)$ statistically significant from infection 400 T. spiralis larvae

already by day 5 p.i., but it did not reach even a half of maximum production of IL-10 on day 10 p.i. in mice with heavy infection. High production of IL-5 was observed after the heavy infection for the overall experiment. A temporal decrease in IL-5 synthesis was recorded in mice with light infection from day 10 to 20 p.i.

Pro-inflammatory Th1 response was not markedly activated after the light infection of mice, IFN- $\gamma$ production was comparable to control till the end of the experiment. After the heavy infection IFN- $\gamma$ production was significantly $(\mathrm{P}<0.01)$ stimulated from day 10 to 45 p.i., that could be associated with the migration of newborn larvae.

Superoxide anion production (Fig.7)

Metabolic activity of peritoneal macrophages was evaluated by in vitro production of superoxide anion $\mathrm{O}_{2}^{-}$, that was significantly inhibited on day 5 p.i. after the heavy infection and it was stimulated later from day 30 to 60 p.i. On the contrary, the light infection increased $\mathrm{O}_{2}{ }^{-}$production early from day 10 to 30 p.i., where were not found significant differences against control, except of days 15 and 30 p.i. Differences between infected groups were recorded on days 5 and 15 p.i. $(\mathrm{P}<0.01 ; \mathrm{P}<0.05)$ and during later phase on days 45 and 60 p.i. $(\mathrm{P}<0.05)$.

\section{Discussion}

The study compares the lymphocyte and macrophage immune response in mice infected with a different size of infective Trichinella spiralis larvae. The low infective dose in the experiment simulated natural conditions of Trichinella infection in small rodents, important reservoirs of

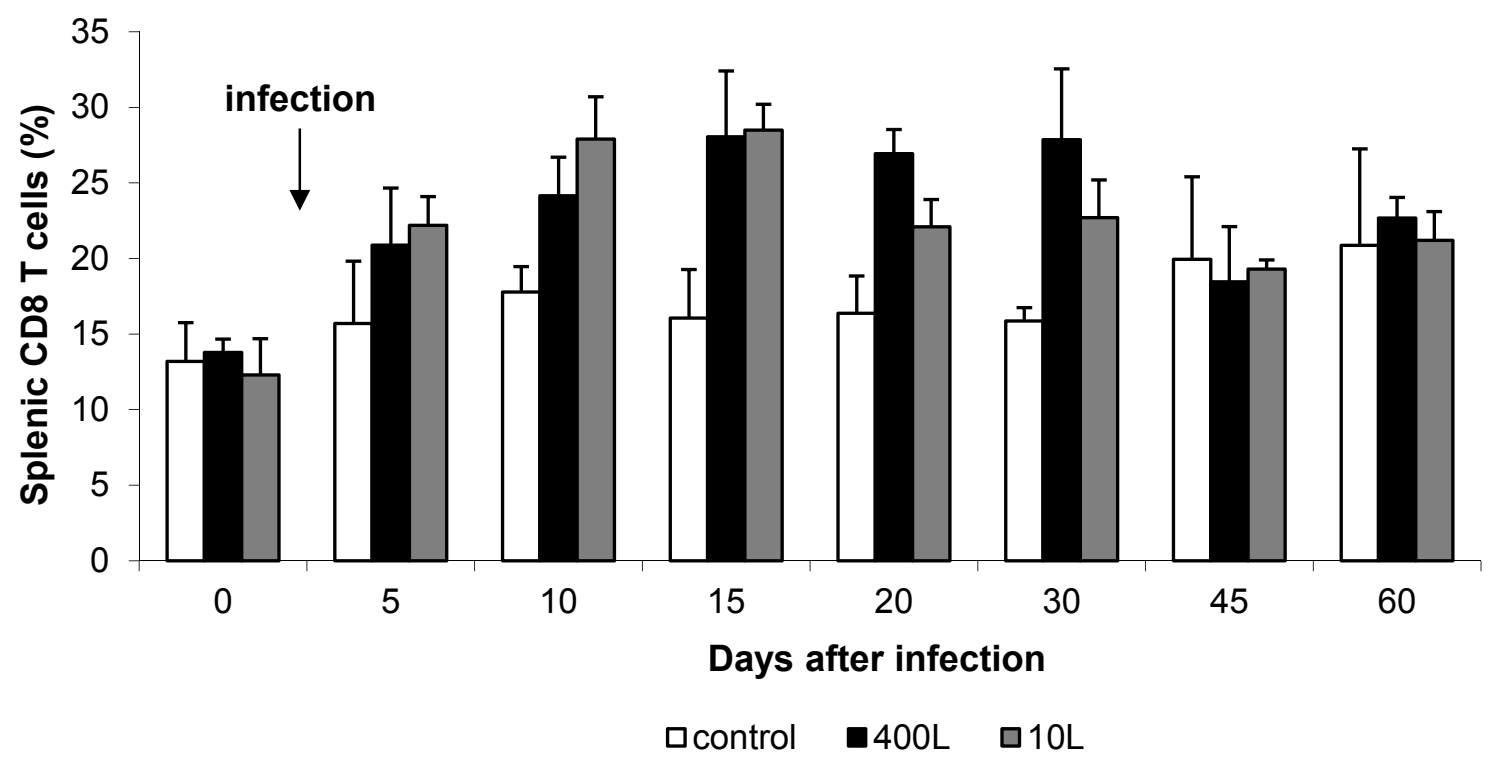

Fig. 4. Relative percentage of splenic CD8+ T cells in mice infected with 10 and 400 T. spiralis larvae 


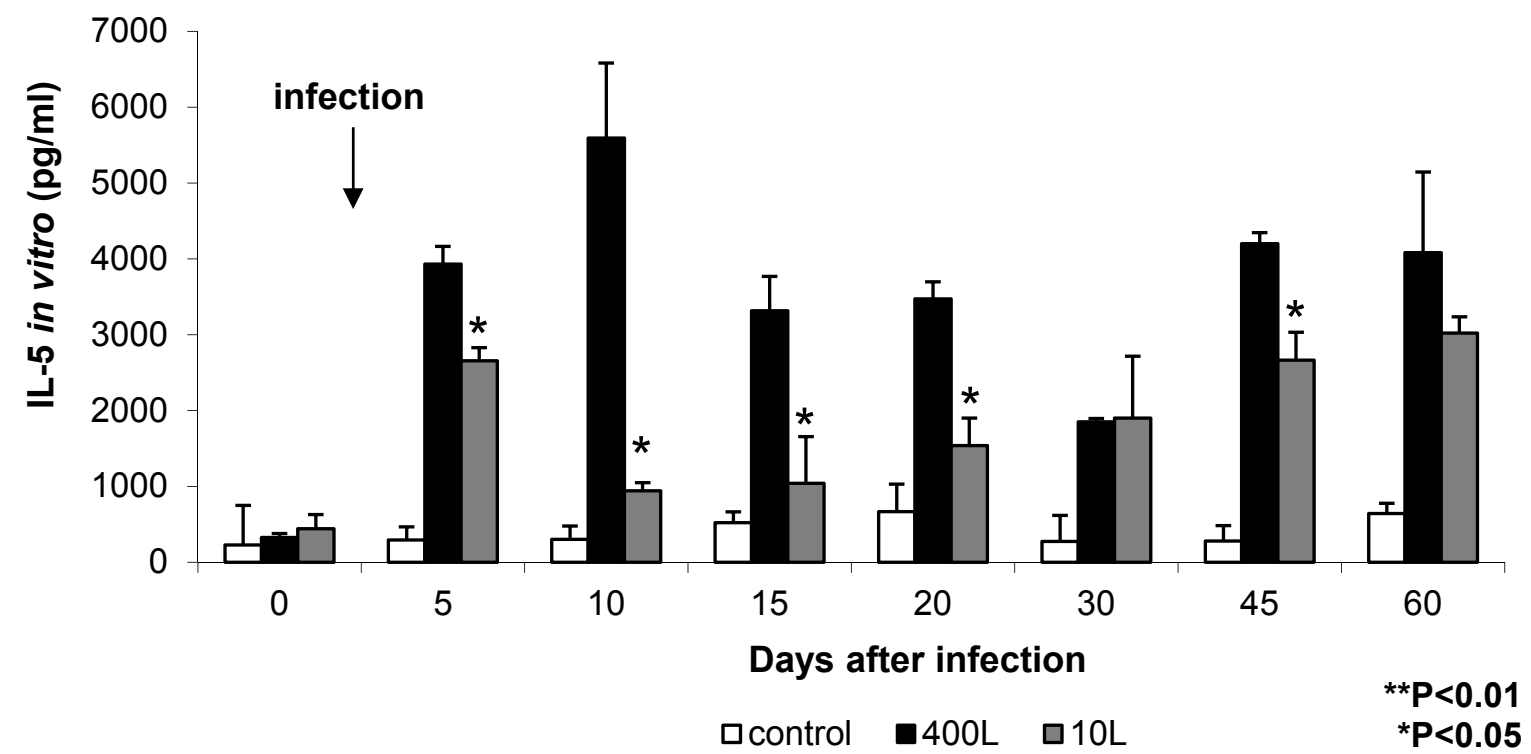

Fig. 5. IL-5 production in vitro by splenocytes of mice infected with 10 and $400 T$. spiralis larvae $*(\mathrm{P}<0.05) ; * *(\mathrm{P}<0.01)$ statistically significant from infection $400 T$. spiralis larvae

trichinellosis. The high infective dose is often used in experimenatal studies to induce trichinellosis.

Parasite burden was quantified in order to compare infectivity of the light and heavy $T$. spiralis infections in this study. The host expulsion of adults from the small intestine was finished by day 15 p.i. after the light infection and day 30 p.i. after the heavy infection. A similar trend of worm persistance, a shorter lasting (20 days) for $T$. spiralis infection with 10 larvae and a longer lasting (30 days) for $T$. spiralis infection with 500 larvae was observed in our previous studies (Dvorožňáková et al., 2005, 2010, 2011). Development from the immature larva to the infective L1 is dependent on infection of skeletal muscle; larvae that penetrate cells are developmentally arrested, implying the parasite is able to recognise the host cell environment
(Despomier, 1998). At the muscle phase of T. spiralis infections the highest numbers of larvae were reached on day 45 or 60 p.i., that is related to the high reproductive capacity of females and finishing of larval migration. The index of reproductive capacity did not differ between light and heavy infections, only a size of the infective dose influenced a parasite number in the host muscles. The highest number of $T$. spiralis larvae ultimately establishing in muscles represents the highest antigenic challenge for its host. In our experimental work the increased proliferative activity of splenic $\mathrm{T}$ lymphocytes was recorded after the light infection only during the intestinal phase, from day 5 to 15 p.i. On the contrary, the heavy infection induced the highest values of proliferative response during the migration of newborn larvae (from day 20 to 30 p.i.). A decrease in

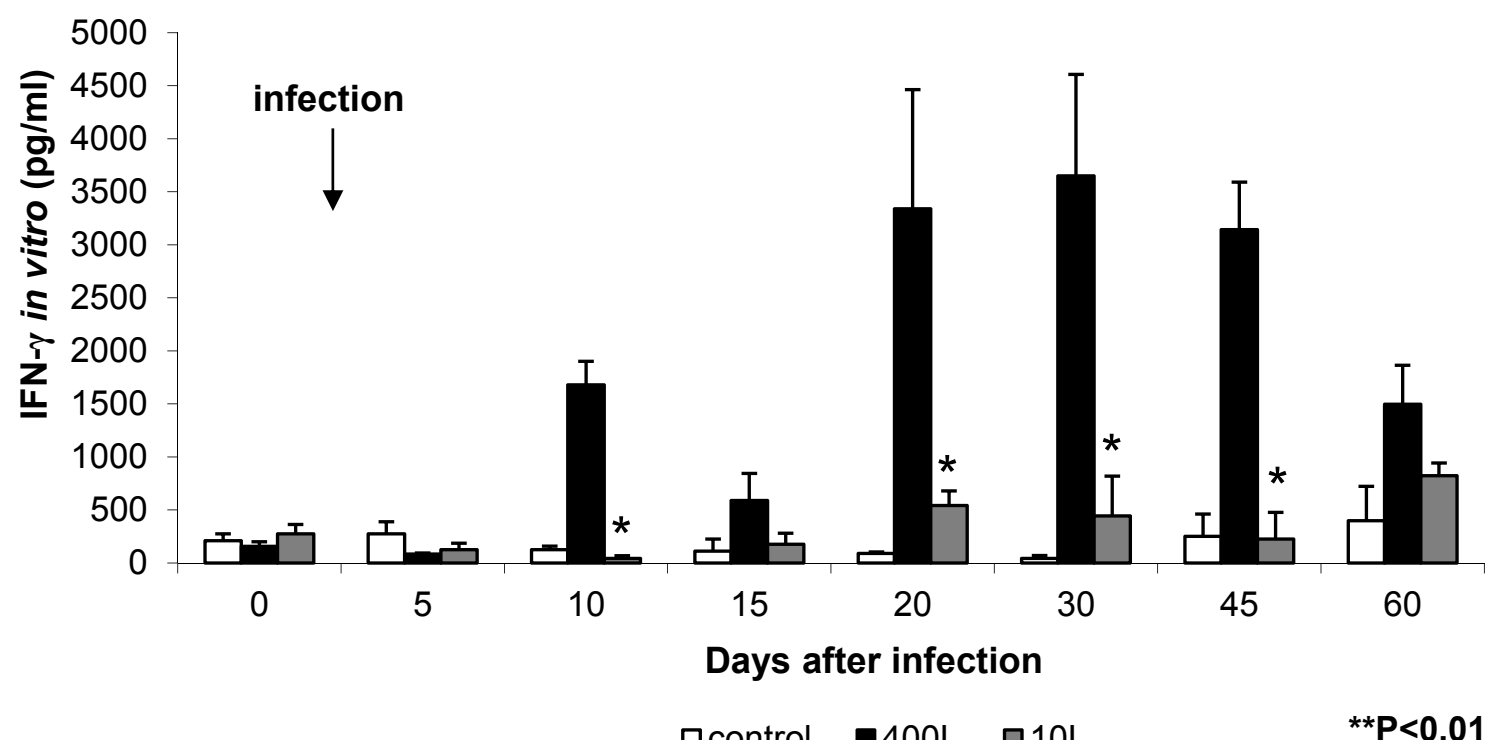

Fig. 6. IFN- $\gamma$ production in vitro by splenocytes of mice infected with 10 and 400 T. spiralis larvae $* *(\mathrm{P}<0.01)$ statistically significant from infection 400 T. spiralis larvae 


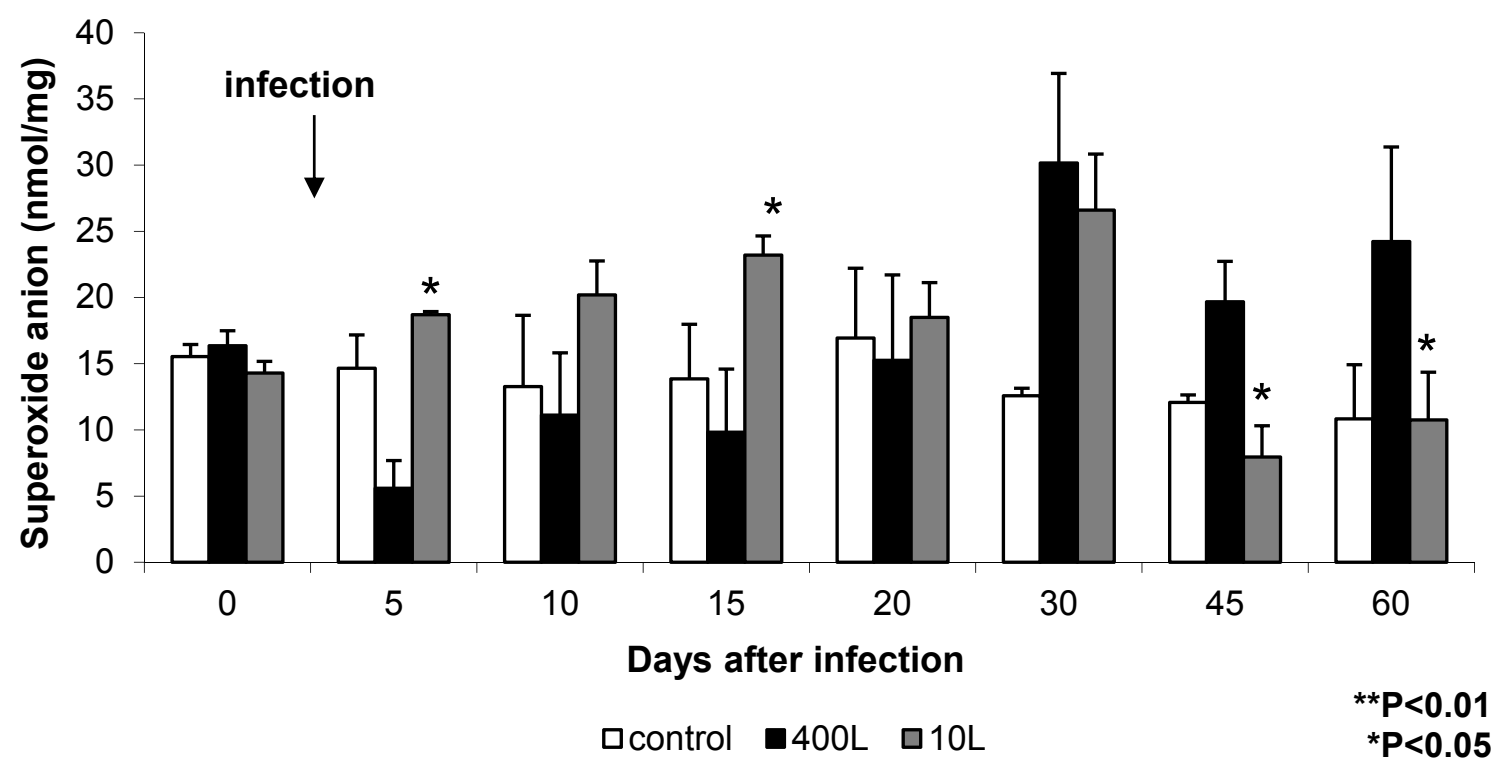

Fig. 7. Superoxide anion production in vitro by peritoneal macrophages of mice infected with 10 and 400 T. spiralis larvae $*(\mathrm{P}<0.05) ; * *(\mathrm{P}<0.01)$ statistically significant from infection 400 T. spiralis larvae

proliferative activity was recorded after day 45 p.i., when the majority of migratory larvae have been settled in muscle cells and have changed the host cell into nurse cell, providing a suitable habitat for the larva. B cell proliferation after both infections did not differ till day 15 p.i. and then the significant stimulation was observed after the heavy infection. Polyclonal lymphocyte activation of Tcells, but particularly B-cells, is responsible for the high levels of immunoglobulines IgG, IgM, and IgE (Murrel \& Bruschi, 1994). In one of the previous studies concerning light Trichinella spp. infection, the proliferation of splenic $B$ cells was stimulated only at the muscle phase, from day 45 p.i., when also seroconversion for specific antibodies was recorded (Dvorožňáková et al., 2010).

T-cells play a central role in immune and inflammatory responses against Trichinella infection (Wakelin \& Grencis, 1992; Dvorožňáková et al., 2005, 2012). Trichinella spp. is a small intestinal parasite, which can induce a strong host immune response of Th2 cells to expel the parasite. During the host immune intestinal response muscular layer of jejunum is infiltrated with CD4 and CD8 T lymphocytes. CD4 $\mathrm{T}$ cells play a key role in trapping and removal of intestinal worms from the gut, they mediate mucosal changes including intestinal goblet cell hyperplasia with high mucin secretion (Ishikawa et al., 1997; Urban et al., 2000). A presence of CD4 and CD8 T cell subpopulations in lymfoid organs reflects a level of $\mathrm{T}$ cell activation and differentiation after the infection (Dvorožňáková et al., 2005). After T. spiralis infection with 400 larvae the occurrence of splenic CD4+ T cells was decreasing till day 15 p.i. and then started to increase. However, the occurrence of CD8+ $\mathrm{T}$ subpopulation was increased from day 5 to 30 p.i. after the heavy infection. Morales et al. (2002) found similar results and supposed that a decrease in CD4 $+\mathrm{T}$ subset was accompanied by a reduction in the number of naive cells and increase in the number of memory cells. Vallance et al. (1999) found in immunodeficient mice with trichinellosis that CD8+ T cells play no significant role in worm expulsion but that CD4+ T cells may make a significant contribution by activation of MHC class II. The important role of CD4 cells on worm expulsion can confirm our results after the light infection. T. spiralis infection with 10 larvae increased the presence of CD4 $\mathrm{T}$ cells from the onset of the infection with the maximum on day 10 p.i. and adults were removed from the intestine after day 15 p.i. Also during the muscle phase of the light infection there was an increased occurrence of CD4 cells in comparison with the heavy infection. The increase of both $\mathrm{T}$ cell populations during the muscle phase of trichinellosis can be associated with larval development in nurse cells, which are surrounded by macrophages, CD8+ and CD4+ T lymphocytes and B lymphocytes (Beiting et al., 2004).

Cytokines synthetized primarily by $\mathrm{T}$ helper cells play a dominant role in orchestrating both anti-parasite responses and pathology in many helminth infections including trichinellosis (Finkelman et al. 1997). In order to examine a relation between Th1 versus Th2 cytokine profiles, levels of marker cytokines were monitored. After the light infection the highest production of Th2 cytokine - IL-5 was found early on day 5 p.i., however it did not even reach a half of maximal production of IL-5 on day 10 p.i. after the heavy infection. A high production of cytokine IL-5 was observed during all experimental days after the heavy infection. Similarly Morales et al. (2002) found in human study a maximal IL-5 production by peripheral blood mononuclear cells 2 months p.i. In mice with the light infection a transient decrease in IL-5 generation was recorded from day 10 to 20 p.i., during newborn larvae migration, but their numbers were low. IL-5 (Th2 cytokine) is a glycoprotein which is secreted mainly from $\mathrm{T}$ helper cells following activation with antigen or mitogen. This is a key 
protein for production, differentiation and activation of eosinophils, B cell growth, and increasing IgA production (Beagley et al., 1988; Kinashi et al., 1986; Hom \& Estridge, 1994). Cytokine IL-5 indicates the severity of inflammation, because it directly induces degranulation of eosinophils (Horie et al. 1996), but it does not increase activity of eosinophils (Kita et al., 1992). Vallance et al. (2000) and Doligalska (2000) confirmed that IL-5 is not only essential for the onset of intestinal eosinophilia, but also makes a significant contribution to enteric host defence during challenge $T$. spiralis infections. IL-5 expression is only minimally protective during a primary $T$. spiralis infection but may protect against repeated exposure to gastrointestinal parasite, what correlated with our results during the intestinal phase after the heavy infection. Thus can be explained a rapid worm expulsion after the light infection with a smaller number of parasites against a longer intestinal phase after the heavy infection.

Proinflammatory Th1 response was not markedly activated after the light infection, the production of IFN- $\gamma$ was comparable to control till the end of the experiment. A significantly increased synthesis of IFN- $\gamma$ was recorded in mice infected with 400 larvae from day 10 to 45 p.i. That could be induced by migration of newborn larvae and higher number of muscle larvae. It has confirmed its participation in immune response at the muscle phase. IFN- $\gamma$ is crucially involved in protection against newborn larvae, but does not affect the expulsion of adult worms (Helmby \& Grencis, 2003). As reported in our previous studies, serum cytokines of mice infected with 500 larvae of $T$. spiralis showed during an early muscle phase higher levels of IFN$\gamma$ and in a late muscle phase of the infection cytokine IL-5 was again predominated (Dvorožňáková et al., 2005, 2012). Also other studies refer to the fact that $T$. spiralis muscle larvae death was correlated with enhanced IFN- $\gamma$ and reduced IL-4 production (Kang et al., 2012). A small number of muscle larvae in mice with the light infection could be a small antigen stimulus to develop inflammatory Th1 response. Numbers of muscle larvae in mice with the light infection were 40 -fold lower than were the parasite burden in mice with the heavy infection.

Mechanism of IFN- $\gamma$ mediated immunity to newborn larvae may include enhanced cytotoxic killing by eosinophils, granulocytes and activated macrophages (Venturiello et al., 1995). Kołodziej-Sobocińska et al. $(2006,2012)$ found an increased metabolic activity of peritoneal macrophages during the first months after infection. In our study metabolic activity of peritoneal macrophages was evaluated by production of superoxide anion $\mathrm{O}_{2}^{-}$. This product was depressed during the intestinal phase after the heavy infection and stimulated in the muscle phase form day 30 to 60 p.i. On the contrary, the light infection increased $\mathrm{O}_{2}{ }^{-}$production already in the intestinal phase, from day 10 to 30 p.i. and during the muscle phase we recorded a small reduction in numbers of muscle larvae on day 60 p.i. This phenomenon could be caused by the destruction of larvae by inflammatory and immune mechanisms and calcification of larvae.
The differences found in the host immune reactions to different infective doses of Trichinella spiralis larvae refer to variations in the development of immune defence against $T$. spiralis infection in experimental models and in natural conditions. Our data suggest that low infective doses of $T$. spiralis larvae stimulate cellular immune response in the first three weeks of infection, when an activation of $\mathrm{CD} 4 \mathrm{~T}$ cells and macrophages is sufficient to eliminate the parasite from the gut, but it does not protect against migration of newborn larvae into the host muscles. However, larvae represent a small antigen stimulation and do not disturb an immunological balance in the host. We confirmed that protective responses can be initiated by very small infections (10 larvae) followed by rapid expulsion of adult worms. Our next aim is to examine of the host immunity after repeated infections with low number of larvae and its efficiency in anti-parasite defence.

\section{Acknowledgements}

This study was supported by the Slovak VEGA agency, grant No. 2/0093/11 and by the Project "INFEKTZOON Centre of Excellence for Animal Infections and Zoonoses (ITMS-26220120002)" on the basis of support from Operational Programme Research and Development, funded by the European Regional Development Fund. The experimental protocols complied with the current Slovak ethics law.

\section{References}

Beagley, K. W., Eldridge, J. H., Kiyono, H., Everson, M. P., Koopman, W. J., Honjo, T., McGhee, J. R. (1988): Recombinant murine IL-5 induces high rate IgA synthesis in cycling IgA-positive Peyer's patch B cells. J. Immunol., 141(6): 2035 - 2042

Beiting, D. P., Bliss, S. K., Schlafer, D. H., Roberts, V. L., Appleton, J. A. (2004): Interleukin-10 limits local and body cavity inflammation during infection with musclestage Trichinella spiralis. Infect. Immun. 72(6): 3129 3137. DOI: 10.1128/IAI.72.6.3129-3137.2004

BOLAS-FERNÁNDEZ, F. (2003): Biological variation in Trichinella species and genotypes. J. Helminthol., 77(2): 111 - 118. DOI: 10.1079/JOH2003170

Cui, J., Wang, Z. Q., Han, H. M. (2006): Congenital transmission of Trichinella spiralis in experimentally infected mice. Helminthologia 43(1): 7 - 10. DOI: 10.2478/s11687-006-0002-4

DESPOMMIER, D. D. (1998): How does Trichinella spiralis make itself at home? Parasitol. Today 14(8): 318 - 323. DOI: $10.1016 / \mathrm{S} 0169-4758(98) 01287-3$

DOLIGALSKA, M. (2000): Immune response to Trichinella spiralis larvae after treatment with the anti-allergic compound ketotifen. Parasitol. Res. 86(3): 232 - 238. DOI: $10.1007 / \mathrm{s} 004360050036$

DVOROŽŇÁKOVÁ, E., HuRNÍKOVÁ, Z., KOŁODZIEJSOBOCIŃSKA, M. (2010): Kinetics of specific humoral immune response of mice infected with low doses of Trichinella spiralis, T. britovi, and T. pseudospiralis larvae. 
Helminthologia 47(3): 152 - 157. DOI: 10.2478/s11687010-0023-x

DVORožŇÁKovÁ, E., HuRníKovÁ, Z., KOŁODZIEJ-SobOCIŃSKA, M. (2011): Development of cellular immune response of mice to infection with low doses of Trichinella spiralis, T. britovi, and T. pseudospiralis larvae. Parasitol. Res. 108(1): 169 - 176. DOI: 10.1007/s00436-010-2049-x DVorožŇÁKOVÁ, E., KoŁODZIEJ-SOBOCIŃSKA, M., HURNíKOVÁ, Z. (2005): Development of T-cell immune response in experimental murine trichinellosis. Helminthologia 42(4): 187 - 196. DOI: 10.2478/s11687-010-0023-x

DVOROŽŇÁKOVÁ, E., KOŁODZIEJ-SOBOCIŃSKA, M., HURNíKOVÁ, Z. (2012): Trichinella spiralis reinfection: changes in cellular and humoral immune response in BALB/c mice. Helminthologia, 49 (4): 201 - 210. DOI: 10.2478/s11687012-0039-5

Finkelman, F. D., Sheadonohue, T., Goldhill, J., Sullivan, C. A., Morris, S. C., Madden, K. B., Gause, W. C., URBAN, J. F. (1997): Cytokine regulation of host defense against parasitic gastrointestinal nematodes: Lessons from studies with rodent models. Ann. Rev. Immunol. 15: 505 - 533. DOI: 10.1146/annurev.immunol.15.1.505

HelmbY, H., GRENCIS, R. K. (2003): IFN-gamma-independent effects of IL-12 during intestinal nematode infection. J. Immunol. 171(7): 3691 - 3696

HOM, J. T., ESTRIDGE, T. (1994): Antigen-induced recruitment of eosinophils: importance of CD4+ T cells, IL5, and mast cells. Clin. Immunol. Immunopathol., 73 (3): 305 311. DOI: $10.1006 /$ clin. 1994.1203

Horie, S., Gleich, G. J., KitA, H. (1996): Cytokines directly induce degranulation and superoxide production from human eosinophils. J. Allergy Clin. Immun., 98(2): 371 - 381. DOI: 10.1016/S0091-6749(96)70161-6

HRČKOVÁ, G., VELEBNÝ, S. (1997): Effect of praziquantel and liposome-incorporated praziquantel on peritoneal macrophage activation in mice infected with Mesocestoides corti tetrathyridia (Cestoda). Parasitology, 114: 475 - 482. DOI: 10.1017/S0031182096008694

HURNÍKOVÁ, Z.; DUBINSKÝ, P. (2009): Long-term survey on Trichinella prevalence in wildlife of Slovakia. Vet. Parasitol., 159(3 - 4): 276 - 280. DOI: 10.1016/j.vetpar. 2008.10.056

ISHIKAWA, N., WAKELIN, D., MAHIDA, Y. R. (1997): Role of $\mathrm{T}$ helper 2 cells in intestinal goblet cell hyperplasia in mice infected with Trichinella spiralis. Gastroenterology, 113(2): 542 - 549. DOI: 10.1053/gast.1997.v113.pm9247474

KANG, S. A., ChO, M. K., PARK, M. K., KIM, D. H., HONG, Y. C., LEE, Y. S., CHA, H. J., OCK, M. S., YU, H. S. (2012): Alteration of helper T-cell related cytokine production in splenocytes during Trichinella spiralis infection. Vet. Parasitol. 186(3 - 4): 319 - 327 DOI: 10.1016/j.vetpar. 2011.12.002

KAPEL, C. M. O., GAMBle, H. R. (2000): Infectivity, persistence, and antibody response to domestic and sylvatic Trichinella spp. in experimentally infected pigs. Int. J. Parasitol. 30(2): 215 - 221. DOI: 10.1016/S00207519(99)00202-7

Khan, W. I., Vallance, B. A., Blennerhassett, P. A.,
Deng, Y., Verdu, E. F., Matthaei, K. I., Collins, S. M. (2001): Critical role for signal transducer and activator of transcription factor 6 in mediating intestinal muscle hypercontractility and worm expulsion in Trichinella spiralis-infected mice. Infect. Immun., 69(2): 838 - 844. DOI: 10.1128/IAI.69.2.838-844.2001

Kinashi, T., Harada, N., Severinson, E., TAnabe, T., Sideras, P., Konishi, M., Azuma, C., Tominaga, A., Bergstedt-LindQvist, S., TaKahashi, M., Matsuda, F.,YAoITA, Y., TAKATSU, K., HonJo, T. (1986): Cloning of complementary DNA encoding T-cell replacing factor and identity with B-cell growth factor II. Nature, 324(6092): 70 - 73. DOI: $10.1038 / 324070 \mathrm{a} 0$

Kita, H., Weiler, D. A., ABU-Ghazaleh, R., SANDERSON, C. J., GLEICH, G. J. (1992): Release of granule proteins from eosinophils cultured with IL-5. $J$. Immunol., 149(2): $629-635$

KOŁODZIEJ-SOBOCIŃSKA, M., MACHNICKA-ROWIŃSKA, B. (2012): In vivo inhibition of inducible nitric oxide synthase by aminoguanidine influences free radicals production and macrophage activity in Trichinella spiralis infected low responders (C57BL/6) and high responders (BALB/c) mice. Helminthologia, 49 (4): 189-200 DOI: 10.2478/ s11687-012-0038-6

KoŁodZIEJ-SobociŃSKA, M; DvorožŇÁKovÁ, E; DZIEMIAN, E. (2006): Trichinella spiralis: Macrophage activity and antibody response in chronic murine infection. Exp. Parasitol. 112(1): 52 - 62. DOI: 10.1016/j.exppara.2005. 09.004

MAHIDA, Y. R. (2003): Host-parasite interactions in rodent nematode infections. J. Helminthol., 77 (2): 125 - 131. DOI: $10.1079 / \mathrm{JOH} 2003172$

Morales, M. A. G., Mele, R., SAnChez, M., Sacchini D., DeGiacomo, M., Pozio, E. (2002): Increased CD8(+)-Tcell expression and a type 2 cytokine pattern during the muscular phase of Trichinella infection in humans. Infect. Immun. 70(1): 233 - 239

MurRell, K. D., BRUSCHI, F. (1994): Clinical trichinellosis. Prog. Clin. Parasitol. 4: $117-150$

Oltean, M., Gavrea, R., Dumitrache, M., Băgut, T., Gherman, C. M., Cozma, V., GyÖrke, A. (2012): Characterization of host-parasite interactions during the experimental Trichinella spiralis infection in pigs. Helminthologia, 49(3): 139 - 146. DOI: 10.2478/s11687-012-0029-7 PARALIČOVÁ, Z., KINČEKOVÁ, J., SCHRÉTER, I., JARČUŠKA, P., DubinskÝ, P. JR., PORUBČIn, Š., PAVLINOVÁ, J., KRISTIAN, P. (2009): Outbreak of trichinellosis in eastern Slovakia. Helminthologia 46(4): 209 - 213. DOI: 10.2478/s11687-009-0039-2

ReiterovÁ, K., ANTOlovÁ, D., HurníkovÁ, Z. (2009): Humoral immune response of mice infected with low doses of Trichinella spiralis muscle larvae. Vet. Parasitol., 159(3-4): 232 - 235. DOI: 10.1016/j.vetpar.2008.10.048 ŠOLTÝs, J., QUINN, M. T. (1999): Modulation of endotoxin- and enterotoxin-induced cytokine release by in vivo treatment with beta-(1,6)-branched beta-(1,3)-glucan. Infect. Immun. 67(1): $244-252$

Urban, J.F., SCHOPF, L., MorRis, S. C., OREKhOVA, T., 
Madden, K. B., Betts, C. J., Gamble, H. R., Byrd, C., Donaldson, D., Else, K., FinKelman, F. D. (2000): Stat6 signaling promotes protective immunity against Trichinella spiralis through a mast cell- and T cell-dependent mechanism. J. Immunol. 164(4): 2046 - 2052

Vallance, B. A., Galeazzi, F., Collins, S. M., Snider, D. P. (1999): CD4 T cells and major histocompatibility complex class II expression influence worm expulsion and increased intestinal muscle contraction during Trichinella spiralis infection. Infect. Immun. 67(11): 6090 - 6097

Vallance, B. A., Matthaei, K. I., Sanovic, S., Young, I. G., Collins, S. M. (2000): Interleukin-5 deficient mice exhibit impaired host defence against challenge Trichinella spiralis infections. Parasite Immunol. 22(10): 487 - 492. DOI: $10.1046 /$ j.1365-3024.2000.00328.x
Venturiello, S. M., Giambartolomei, G. H., CostantinO, S. N. (1995): Immune cytotoxic activity of human eosinophils against Trichinella spiralis newborn larvae. Parasite Immunol. 17(11): 555 - 559. DOI: 10.1111/j.1365-3024.1995.tb00998.x

WAKELIN D., GRENCIS R. K. (1992): T cell and genetic control of intlammatory cells. In: MOQBEL, R. (ed.) Allergy and Immunity to Helminths, Taylor a Francis, London, UK, pp. 108 - 136

Wakelin, D., Farias, S. E., Bradley, J. E. (2002): Variation and immunity to intestinal worms. Parasitology, 125(S): S39 - S50. DOI: 10.1017/S0031182002001440

WANG, C. H. (1997): Study of biological properties of Trichinella spiralis newborn larvae and the antiparasitic mucosal immunity of the host. Front. Biosci., 2: d317 - 330 